\title{
EFEKTIVITAS PEPAYA (Carica Papaya L) TERHADAP KELANCARAN PRODUKSI ASI PADA IBU MENYUSUI
}

\author{
${ }^{1)}$ Ifni Wilda ${ }^{2)}$ Nelfi Sarlis \\ Akademi Kebidanan Sempena Negeri Pekanbaru \\ Jl. Soekarno Hatta gg. Handayani 1 No.1 Arengka Atas Pekanbaru \\ *email: ${ }^{1}$ ifniwilda1@ gmail.com, ${ }^{2}$ sarlisnelfi@gmail.com
}

\section{Kata Kunci: \\ Carica Papaya L, Produksi ASIIbu Menyusui}

\section{Keywords: \\ Carica Papaya L, Breastfeeding,}

\section{Info Artikel}

Tanggal dikirim: 16-02-2021 Tanggal direvisi: 02-04-2021 Tanggal diterima: 22-07-2021 DOI Artikel:

10.36341/jomis.v5i2.1692

Creative Commons AttributionNonCommercial-ShareAlike 4.0 International License.

\begin{abstract}
ABSTRAK
ASI atau singkatan dari Air Susu Ibu dari sisi kuantitas atau kualitas memiliki komposisi nutrisi yang optimal, tetapi Cakupan ASI di Indonesia belum mencapai hasil yang ditargetkan yaitu 61,50\%. Cakupan pemberian ASI Ekslusif di beberapa kabupaten di Provinsi Riau sudah mencapai target yang diharapkan tetapi kabupaten Kuantan Singigi termasuk kabupaten dengan pencapaian terendah yaitu $68 \%$ bila dibandingkan pencapaian kabupaten lain yang berkisar diatas $70 \%$. Polifenol dan steroid didalam buah pepaya mempengaruhi reflek prolaktin untuk merangsang alveolus yang bekerja aktif dalam pembentukan ASI dan polifenol juga mempengaruhi hormon oksitosin yang akan membuat ASI mengalir lebih disamping kandungan laktogogum yang memiliki manfaat melancarkan dan meningkatkan pengeluaran ASI. Penelitian ini bertujuan untuk mengetahui efektivitas pepaya muda (carica papaya $L$ ) terhadap kelancaran produksi ASI. Jenis penelitian adalah yaitu quasi eksperimen. Penelitian ini di lakukan di Wilayah Kerja Puskesmas Sentajo Raya Teluk Kuantan tahun 2020. Sampel dalam penelitian ini ibu menyusui dengan usia bayi $<6$ bulan berjumlah 15 responden dengan teknik consecutive sampling. Teknik analisis data dalam penelitian ini adalah dengan univariat dan bivariate menggunakan uji Wilcoxon dengan hasil adanya efektivitas pepaya muda terhadap kelancaran produksi ASI,dengan nilai p value 0,001. Direkomendasikan kepada tenaga kesehatan di puskesmas Sentajo Raya untuk meningkatkan pengetahuan tentang terapi nonfarmakologi dalam meningkatkan produksi ASI khususnya efektivitas pepaya muda terhadap kelancaran menyusui.
\end{abstract}

\section{ABSTRACT}

ASI or the abbreviation of Breast Milk in terms of quantity or quality has an optimal nutritional composition, but the coverage of breast milk in Indonesia has not reached the targeted result, which is $61.50 \%$. Exclusive breastfeeding coverage in several districts in Riau Province has reached the expected target, but Kuantan Singgigi district is one of the districts with the lowest achievement, which is $68 \%$ when compared to the achievement of other districts which are above 70\%. Polyphenols and steroids in papaya affect the prolactin reflex to stimulate the alveoli which work actively in the formation of breast milk and polyphenols also affect the hormone oxytocin which will make breast milk flow more in addition to the content of laktogogum which has the benefit of launching and increasing breast milk expenditure. This study aims to determine the effectiveness of young papaya (Carica papaya L) on the smooth production of breast milk. This type of research is quasi-experimental. This research was conducted in the Working Area of the Sentajo Raya Public Health Center Teluk Kuantan in 2020. The sample in this study was breastfeeding mothers with infants aged < 6 months totaling 15 respondents using a consecutive sampling technique. The data analysis technique in this study was univariate and bivariate using the Wilcoxon test with the results of the effectiveness of young papaya on the smooth production of breast milk, with a p value of 0.001. It is recommended for health workers at the Sentajo Raya Public Health Center to increase knowledge about nonpharmacological therapies in increasing breast milk production, especially the effectiveness of young papaya for smooth breastfeeding. 


\section{PENDAHULUAN}

ASI ekslusif yakni pemberian ASI saja kepada bayi tanpa makanan tambahan apapun kecuali obat dan vitamin direkomendasikan oleh organisasi kesehatan dunia yaitu World Health Organization (WHO) untuk diberikan kepada bayi sampai berumur 6 bulan.. Rekomendasi ini dianjurkan karena ASI steril dan komposisinya sesuai dengan zat gizi yang dibutuhkan bayi. Pemberian makananan pendamping ASI yang terlalu cepat dari waktunya ditambah lagi dengan makanan yang rendah zat gizi dan energi atau tidak higienis dapat mengakibatkan kekurangan gizi pada anak, dan anak akan terkontaminasi organisme asing yang mengakibatkan imunitas anak lebih rendah dari anak yang diberikan ASI Eksklusif (Kementerian Kesehatan RI Badan Penelitian dan Pengembangan, 2018).

Indonesia berada pada peringkat ke -3 terbawah dari 51 negara yang ikut pada penilaian status kebijakan dan program pemberian makan bayi dan anak (Infant-Young Child Feeding) (Prasetyaningati, 2018). Hal ini berarti pemberian ASI ekslusif masih rendah, padahal dengan memberikan ASI Eklusif dan Makanan Pendamping ASI yang benar dapat mengurangi kekurangan gizi, gizi buruk dan stunting pada anak.

Cakupan pemberian ASI Ekslusif di Provinsi Riau Tahun 2016 yaitu 56,2\% masih rendah dibanding targetnya (80\%) cakupan ini mengalami penurunan dibandingkan tahun 2015 sebesar $68,8 \%$. Sebagai contoh penelitian yang dilakukan ((Wilda, Ifni, 2018) di wilayah kerja Puskesmas Sidomulyo diperoleh hasil sebanyak $71 \%$ ibu tidak memberikan ASI ekslusif. Penelitian (Bahriyah et al., 2017) di Puskesmas Sipayung diperoleh hasil sebanyak 49,3\% ibu tidak memberikan asi Ekslusif.

Tahun 2019, Kabupaten/Kota tertinggi Pemberian ASI Ekslusif adalah Kabupaten Siak yakni 58,96\% diikuti Kabupaten Rokan Hilir sebesar 57,57\%, dan Kabupaten Meranti sebesar 53,06\%. Kabupaten terendah pemberian ASI adalahKabupaten Kuansing sebesar 24,36\%, diikuti oleh Kabupaten Indragiri Hilir sebesar 30,06\%. Berdasarkan hasil diatas, dapat diketahui hanya 3 kabupaten yang telah mencapai target program ASI (Riau, 2019).

Mengkonsumsi sayur-sayuran dapat meningkatkan produksi ASI. Selama ini ibu menyusi kebanyakan hanya mengonsumsi sayur daun katu untuk memperlancar produksi ASI nya, padahal ada papaya muda (Carica papaya $L$ ) yang juga memiliki kandungan laktogogum seperti daun katu berfungsi dalam peningkatan dan kelancaran ASI.

Pepaya muda adalah buah tropis dengan kandungan laktogogum (Istiqomah, Wulandari, 2015). Selain itu, pepaya juga mengandung enzim-enzim yang memberikan efek meningkatkan jumlah dan diameter kalenjer mamae, vitamin C, A, B dan E, serta mineral. Kandungan kimia buah pepaya muda mengandung polifenol, dan steroid. Polifenol dan steroid dalam papaya dapat meningkatkan kerja hormone prolactin yang merangsang alveolus untuk membentuk ASI. Polifenol dan Steroid juga berpengaruh pada kerja homron oksitosin untuk mengalirkan ASI, sehingga ASI lebih deras mengalir pada ibu yang mengkonsumsi buah papaya dibandingkan ibu yang tidak mengkonsumsinya. (Istiqomah, dkk, 2014). Selain Lactogogum, didalam buah papaya juga mengandung pati $(43,28 \%)$, gula $(15,15 \%)$, protein $(13,63 \%)$, lemak $(1,29 \%)$ kelembaban (10,65\%), serat $(1,88 \%)$. Kandungan bahan tersebut menjadikan buah papaya sebagai buah yang kaya akan nutrisi dan dapat digunakan sebagai bahan pengobatan (Kharisma, 2017).

Berdasarkan pra riset yang peneliti lakukan pada 10 orang ibu menyusui tidak ada satupun ibu menyusui mengetahui bahwa sayur pepaya muda dapat meningkatkan produksi ASI padahal buah pepaya banyak diminati dan sudah umum di masyarakat dan rata-rata ibu menyukai sayur daun pepaya muda karena dapat meningkatkan nafsu makan.

\section{TINJAUAN PUSTAKA}

Pepaya didalam bahasa latin disebut Carica Papaya termasuk kedalam buah tropis 
yang memiliki kandungan Laktogogum. Laktogogum adalah zat yang mengakibatkan pengeluaran air susu ibu (ASI) menjadi lancar dan produksinya menjadi meningkat (Istiqomah, Wulandari, 2015).

Pepaya adalah salah satu tanaman yang paling banyak dibudidayakan di negara tropis dan spesies yang paling populer dan penting secara ekonomi di antara keluarga Caricaceae. Meskipun hanya buahnya yang umumnya digunakan sebagai produk komersial, di beberapa negara Asia Pasifik, daunnya juga digunakan sebagai obat tradisional untuk pengobatan asma, kolik, demam, beri-beri (India), malaria dan demam berdarah (SriLanka, Pakistan dan Malaysia), serta kanker (Vietnam dan Australia). Di Indonesia daunnya dikonsumsi sebagai sayuran, teh, dan obat tradisional (disebutjamu) untuk berbagai tujuan seperti meningkatkan nafsu makan dan produksi ASI, menurunkan demam, serta mencegah dan menyembuhkan malaria (Nugroho et al., 2017)

Pemanfaatan produk pepaya muda lokal yang alami telah banyak ditemukan seperti untuk kesehatan mata, untuk asimilasi, dimanfaatkan sebagai sayuran untuk pemenuhan protein dan zat gizi, serta dikonsumsi untuk mendorong dan menambah kuantitas Air Susu Ibu. Pepaya muda dapat diolah dengan cara ditumis dan dikukus. Pepaya merupakan salah satu makanan yang memiliki banyak keunggulan dan mudah didapat oleh masyarakat karena efektif untuk ditanam di halaman rumah. bahan pepaya yang alami dapat menambah jumlah ASI dan dapat membantu mencapai program pemerintah dalam upaya pemberian ASI secara eksklusif yaitu pemberian ASI sampai bayi mencapai usia setengah tahun, dilanjutkan menyusui sampai 2 tahun ditambah dengan makanan padat.

Bertambahnya jumlah ASI dipengaruhi oleh adanya polifenol dan steroid yang mempengaruhi refleks prolaktin untuk membuat alveoli menjadi fleksibel dalam mengeluarkan ASI. Pertumbuhan produksi payudara juga diperkuat oleh oksitosin kimia, peningkatan oksitosin kimia dipengaruhi oleh polifenol dalam pepaya muda yang akan membuat aliran susu payudara lebih baik dibandingkan dengan sebelum makan pepaya. Oksitosin adalah bahan kimia yang memberi energi pada emisi susu (milklet down). Bagian oksitosin dalam kelenjer susu adalah untuk mendukung kompresi sel-sel miopitel yang melingkupi alveoli untuk didorong keluar ke dalam pipa susu, sehingga alveoli menjadi kosong dan mensintesis air susu berikut nya (Istiqomah, 2014).

Perbedaan peningkatan produksi ASI pada ibu yang tidak memakan dan memakan produk alami pepaya adalah $3,15 \%$, Hal ini menunjukkan peningkatan produksi ASI pada ibu menyusui yang diberi produk organik pepaya selama 7 hari berturut-turut. Mengkonsumsi produk alami pepaya secara konsisten sebanyak 124 gram selama 7 hari dapat menambah produksi ASI (Murtiana,2011).

Pada tahun pertama kehidupan masa pertumbuhan berat badan bayi dibagi menjadi dua, yaitu usia 0-6 bulan dan usia 6-12 bulan. Untuk usia 0-6 bulan mengalami penambahan berat badan setiap minggu 140- 200 gram, berat badan akan menjadi dua kali berat badan lahir pada akhir bulan ke-6. Pada usia 6-12 bulan terjadi penambahan berat badan setiap minggu 85-400 gram. Berat badan akan meningkat sebesar 3 kali berat badan lahir pada akhir tahun pertama. Anak mengalami kenaikan berat badan dua kali menjelang akhir setengah tahun pertama. Sementara itu, pada usia 6 tahun, berat badan bertambah setiap minggunya berkisar 85-400 gram. Berat badan akan bertambah beberapa kali lipat dari berat lahir menjelang akhir tahun pertama (Hidayat, 2008).

Pada waktu yang lain, Hidayat (2008) mengungkapkan bahwa tubuh anak diklasifikasikan menjadi dua, yakni pada usia 0-6 bulan dan 6 tahun. Untuk waktu 0-6 bulan, berat badan anak akan bertambah setiap minggu sekitar 200-300 gram dan berat badannya akan menjadi beberapa kali lipat dari berat lahir menjelang akhir bulan ke-6. Umur 6 tahun terjadi pertambahan secara konsisten sekitar 240-400 gram dan menjelang akhir bulan ke 12 akan bertambah beberapa kali lipat dari berat lahirnya. 
Bertambahnya produksi ASI disebabkan oleh rangsangan hormon oksitosin. Peningkatan hormon oksitosin dipengaruhi oleh polifenol yang ada pada buah pepaya yang akan menimbulkan ASI mengalir lebih banyak dari pada sebelum mengkonsumsi butir pepaya. Oksitosin merupakan hormon yg berperan buat mendorong sekresi air susu (milk let down). Peran oksitosin dalam kelenjar susu yaitu mendorong kontraksi sel miopitel yg mengelilingi alveolus, sebagai akibatnya dengan berkontraksinya sel miopitel isidari alveolus akan terdorong menuju saluran susu, sehingga alveolus menjadi kosong \& memacu buat sintesis air susu berikutnya. (Murtiana,2011). Laktogogum mengandung bahan aktif yang bekerja seperti halnya Prolactin Releasing Hormon (PRH) yang mengandung bahan aktif senyawa steroid yang memiliki kegunaan seperti prolaktin dan oksitosin.

Hasil dalam penitilian ini sejalan dengan penelitian yang dilakukan (Nataria \& Oktiarini, 2018) tentang produksi ASI dengan konsumsi buah pepaya. Perbedaan setelah dan sebelum diberikan buah papaya adalah 9,27, nilai standar deviasi 0,108 . Hasil uji bivariat diperoleh nilai p-value 0,0005 yang menjelaskan bahwa terdapat perbedaan jumlah ASI sesudah dengan sebelum diberikan papaya.

Penelitian (Istiqomah, Wulandari, 2015) yang berjudul pengaruh pemberian buah pepaya muda terhadap kelancaran produksi ASI pada ibu menyusuijuga mendukung penelitian ini dengan nilai $\mathrm{P}$ Value $=0,0005$ $(p<0,05)$ yang berarti terdapat pengaruh pemberian buah pepaya muda terhadap kelancaran ASI.

Lactagogum adalah obat dapat meningkatkan atau memperlancar mengeluarkan susu. Laktagogum yang diproduksi dan telah diolah umumnya cukup mahal. Hal ini membuat perlu dicari obatobatan laktagog elektif. Produksi ASI dari segi kuantitas dan kualitasa dilakukan dengan melakukan perawatan payudara dari awal, prosedur pemurnian menyusui, atau dengan mengkonsumsi makanan yang bisa mempengaruhi pembuatan air susu. budaya
Indonesia memiliki praktik atau kecenderungan menggunakan kemampuan alam, kedua tumbuhan dan makhluk sebagai bahan pengikat terapeutik. Di Indonesia ada 7.000 jenis tanaman restoratif, bagaimanapun juga yang telah dimanfaatkan secara rutin di industri obat tradisional (OT). Sebagian besar Tanaman ini diambil langsung dari alam Selain itu, ada juga yang telah dikembangkan. Indonesia adalah salah satu negara tersebut kaya akan berbagai jenis tanaman padat sebagai tanaman terapi. Beberapa yang berfungsi sebagai laktagogum misalnya tanaman katuk, lampes, adas manis, bayam onak, bidara upas, blustru, ayam dadap, jintan hitam yang keras, kelor, nangka, patikan kebo, pulai, jahe, turi, dan produk organik pepaya awet muda.

Penelitian yang dilakukan oleh $(\mathrm{Br}$ Sebayang (2020) juga mendukung penelitian ini dengan nilai p-value 0,003 yang bermakna produksi ASI meningkat pada ibu menyusui yang diberikan buah papaya. Penelitian (Aliyanto \& Rosmadewi(2019) yang meneliti tentang "keefektifan sayur papaya dan daun kelor terhadap produksi ASI pada ibu Postpartum" juga menunjukkan hasil terdapat penambahan berat badan bayi pada ibu yang diberikan sayurat tersebut dengan nilai $\mathrm{p}$ value 0,01 .

Pada penelitian (Muhartono, et.al 2018) yang berjudul "Pengaruh Pemberian Buah Pepaya (Carica Papaya L.) terhadap Kelancaran Produksi Air Susu Ibu (ASI) pada Ibu Menyusui" dimana buah pepaya dapat meningkatkan sekresi dan jumlah produksi ASI.

Sejalan dengan penelitian (Wirdaningsih, 2020) yang berjudul "Pengaruh pemberian buah papaya terhadap kelancaran asi pada ibu menyusui Di praktek mandiri bidan wilayah Kerja puskesmas Muara Badak" didapatkan hasil Ada pengaruh pemberian buah pepaya terhadap kelancaran ASI pada ibu menyusui ( $p$ value $0,001<0,05)$.

\section{METODE}

Penelitian ini adalah penelitian kuantitatif dengan menggunakan quasi ekperimen. 
Penelitian dilaksanakan di Wilayah Kerja Puskesmas Sentajo Raya Teluk Kuantan pada tanggal 29 Mei 2020 - 5 Juni 2020. Sampel adalah ibu menyusui yang memiliki bayi berusia dibawah 6 bulan dengan kriteria inklusi adalah ibu yang memiliki bayi usia $<6$ bulan, menyusui ekslusif dan bersedia untuk menjadi responden dalam penelitian ini. Data dikumpulkan dengan data primer dan observasi (pengamatan) secara langsung. Penilaian kelancaran produksi asi diukur dengan indicator kenaikan berat badan bayi..
Analisa data yang peneliti gunakan adalah Univariat dan Bivariat. Pertama kali dilakukan analisis univariat untuk mendapatkan data tentang karakteristik subjek penelitian. Setelah itu untuk melihat efektivitas pepaya muda (carica papaya $L$ ) terhadap kelancaran ASI ibu menyusui dengan uji parametrik yaitu uji $\mathrm{t}$ dependen (syarat data telah di uji normalitas dan uji homogenitas). apabila nilai probabilitas $(p)<0,05$ maka Ho ditolak dan Ha diterima. Apabila $(p)>0,05$ maka Ho diterima dan $\mathrm{Ha}$ ditolak.

\section{HASIL DAN PEMBAHASAN}

Tabel Rerata Peningkatan Berat Badan Bayi Sebelum dan Sesudah Diberikan Pepaya Muda (Carica Papaya L)

\begin{tabular}{cccccc}
\hline & N & Mean & $\begin{array}{c}\text { Standar } \\
\text { deviasi }\end{array}$ & Minimum & Maksimum \\
\hline $\begin{array}{c}\text { Berat badan bayi sebelum } \\
\text { diberikan sayur pepaya muda }\end{array}$ & 15 & 3567 & 20,814 & 4 & 66 \\
\hline $\begin{array}{c}\text { Berat badan bayi sesuda } \\
\text { diberikan sayur pepaya muda }\end{array}$ & 15 & 4520 & 13,359 & 4 & 68 \\
\hline
\end{tabular}

Hasil Tabel 1 diatas diperoleh perbedaan rerata berat badan bayi sebelum dan sesudah diberikan papaya muda menggunakan uji Wilcoxon. Rerata berat badan bayi sebelum ibu diberikan papaya adalah 3567 gram, sedangkan rerata berat badan bayi setelah ibu diberikan papaya adalah 4520 gram.

\section{Tabel Efektivitas Pepaya Muda (Carica Papaya L) Terhadap Kelancaran Produksi ASI Ibu Menyususi berdasarkan rata-rata penambahan berat badan bayi}

\begin{tabular}{llcccc}
\hline & & N & $\begin{array}{l}\text { Mean } \\
\text { Rank }\end{array}$ & $\begin{array}{l}\text { Sum of } \\
\text { Range }\end{array}$ & $\begin{array}{l}\text { Asyimp } \\
\text { Sign } \\
\text { (Tailed) }\end{array}$ \\
\hline $\begin{array}{l}\text { Berat badan setelah diberikan daun } \\
\text { papaya muda }\end{array}$ & $\begin{array}{l}\text { Negatif Rank } \\
\text { Positif Rank }\end{array}$ & 0 & 0,00 & 0,00 & $-3,266$ \\
$\begin{array}{l}\text { Berat badan sebelum diberikan daun } \\
\text { papaya muda }\end{array}$ & Ties & 13 & 7,00 & 91,00 & 0,001 \\
\hline & Total & 2 & & & \\
\hline
\end{tabular}

Berdasarkan tabel Uji Wilcoxon Signed Ranks Test di atas menunjukkan bahwa bayi yang mengalami kenaikan berat badan sesudah di berikan pepaya muda kepada ibu menyusui berjumlah 13 orang. Sedangkan bayi yang tidak mengalami kenaikan berat badan sebanyak 2 orang. Berdasarkan uji Statistik
Wilcoxon, didapatkan nilai $\mathrm{p}=0,001$ sehingga Ho ditolak maka disimpulkan ada efektivitas pepaya muda terhadap kelancaran produksi ASI.

Produk organik pepaya adalah tanaman yang mengandung laktogogum yang tampaknya menghidupkan bahan kimia oksitosin dan prolaktin seperti alkaloid, 
polifenol, steroid, flavonoid, dan zat lain yang paling baik dalam meningkatkan ASI. Kapasitas prolaktin kimiawi untuk pembuatan ASI.

Dorongan neorohormonal terjadi saat bayi mengisap areola ibu. dorongan neorohormonal deteruskan ke hipofisis melalui nervosvagus dan kemudian ke lobus bagian depan.

Dari lobus ini prolactin dikeluarkan ke sistem peredaran darah hingga tiba pada kelenjar-kelenjar yang akan menghasilkan ASI. Kelenjar ini akan mendapatkan rangsangan untuk memproduksi (Murtiana, 2011)

Peningkatan produksi susu dipengaruhi oleh adanya polifenol dan steroid yang mempengaruhi refleks prolaktin mengaktifkan alveoli yang bersifat dinamis dalam menghasilkan ASI. Produksi ASI juga digerakkan oleh oksitosin, peningkatan oksitosin kimia dipengaruhi oleh polifenol dalam pepaya muda yang akan membuat aliran susu menjadi lebih banyak daripada sebelum pepaya dikonsumsi. Oksitosin merupakan bahan kimia yang berperan dalam pemberdayaan emisi susu (milklet down). Bagian oksitosin pada organ mammae adalah untuk mendukung kompresi sel-sel miopitel yang melingkupi alveoli untuk didorong keluar ke dalam saluran susu, sehingga alveoli menjadi kosong dan lonjakan untuk produksi air susu berikutnya (Istiqomah,2014)

Hal ini menjelaskan bahwa ASI meningkat pada ibu menyusui yang telah diberi pepaya muda selama 7 hari lamanya. Hasil penelitian sejalan dengan teori Lingga dalam (Murtiana 2011), yang menjelaskan bahwa terdapat beberapa senyawa didalam buah pepaya yang berhubungan dengan penambahan jumlah ASI beserta kualitasnya. Polifenol dan Steroid merangsang hormone prolactin dalam meningkatkan jumlah ASI dimana hormone prolactin ini membuat alveoli payudara menjadi aktif untuk memproduksi air susu ibu.

Penelitian Istiqomah, et.al (2014) mendukung hasil penelitian ini, dimana penelitian tersebut berjudul tentang "pengaruh pemberian buah pepaya muda terhadap kelancaran produksi ASI pada ibu menyusui" yaitu uji Paired T-Test didapatkan nilai $\mathrm{p}=0,0005(\mathrm{p}<0,05)$ yang berarti konsumsi buah pepaya muda memberi pengaruh dalam melancarkan pembuatan ASI.

Dalam penelitian yang diarahkan oleh Sri et.al (2015) dengan teknik metode eksperimen atau intervensi satu kelompok, dimana kelompok tersebut menjadi kelompok kontrol sekaligus kelompok intervensi. Dengan hasil produksi susu normal sebelum mengkonsumsi buah pepaya adalah 5,7 kali dengan standar deviasi 0,813. Setelah mengkonsumsi buah pepaya didapatkan hasil 9,75 kali dengan deviasi standar 0,78640. Perbedaan nilai rerata sebesar 4,05000 dengan P Value 0,000, hal ini diasumsikan bahwa produksi ASI sebelum dan sesudah mengkonsumsi buah pepaya terdapat perbedaan dan buah pepaya membuat produksi ASI menjadi lebih banyak dan lancar.

Penelitian yang dilakukan (Ikhlasiah, 2020) tentang pengaruh jus daun pepaya bagi ibu menyusui dan ibu bekerja terhadap peningkatan kadar hormon prolaktin dan berat badan bayi di Tangerang. Rancangan penelitian menggunakan model pra eksperimental dengan rancangan one group pretest-posttest design. Sampel yang diambil sebanyak 10 ibu yang mempunyai bayi usia 0 6 bln yang mengalami kesulitan menyusui karena jumlah ASI yang sedikit. Penelitian dilakukan di beberapa klinik di Tangerang. Intervensi pemberian perasan daun pepaya selama 7 hari berturut-turut. Hasil yang diperoleh dari penelitian ini adalah sebagai berikut: 90 persentase ibu berusia antara 20 dan 35 tahun, 70 persentase ibu memiliki riwayat persalinan spontan dan tidak mengalami komplikasi pada saat persalinan, 40 persentase pendidikan ibu adalah SLTP (SMP), dan 70 persentasi ibu adalah primipara. Peningkatan rata-rata jumlah prolaktin setelah intervensi adalah 19,59 $\mathrm{ng} / \mathrm{ml}$, sedangkan rata-rata pertambahan berat badan bayi baru lahir setelah intervensi adalah $165 \mathrm{~g}$. Hasil uji Wilcoxon untuk peningkatan kadar p-value hormon prolaktin 0,047 dan untuk peningkatan bobot badan bayi baru lahir p-value 0,009 $<0,05$ sehingga disimpulkan terdapat pengaruh pemberian jus daun pepaya pada ibu menyusui yang bekerja terhadap peninpgkatan kadar 
hormon prolaktin dan berat badan bayi di Tangerang. Jus daun pepaya bisa menjadi galaktagog bagi para ibu yang mengalami masalah dengan ASI dalam jumlah sedikit.

Penelitian (Wijayanti1 et al., 2019) tentang Cookies daun pepaya Carica mengandung $0,01 \mathrm{mg} / \mathrm{g}$ mangan. Kebutuhan mangan untuk wanita dewasa adalah $1.8 \mathrm{mg} /$ hari. Selama masa menyusui, wanita membutuhkan tambahan $0.8 \mathrm{mg}$ tambahan mangan per hari. Jadi $2.6 \mathrm{mg}$ mangan dibutuhkan ibu menyusui setiap hari.18 Dua potong 25 gramg cookie mengandung $0,50 \mathrm{mg}$ mangan yang berkontribusi menjadi 19,2 persentase kebutuhan mangan untuk ibu menyusui. Mangan dan kalium dapat merangsang produksi dan aktivitas prolaktin dan oksitosin. Konten mangan pada kukis daun Carica merangsang kelenjar pituitary dalam memproduksi prolaktin, yg meningkatkan ASI. Kekurangan kalium menyebabkan kelelahan dan perubahan suasana hati yg menghambat produksi oksitosin. Kalium memiliki efek relaksasi, sehingga dapat merangsang produksi oksitosin yang dibutuhkan untuk pengeluaran ASI.

Penelitian ini menemukan bahwa daun Carica papaya yang direbus dua kali pada suhu $60^{\circ} \mathrm{C}$ selama 10 menit mengalami kerusakan $\mathrm{pH}$ paling rendah dibandingkan direndam dalam 2,5\% volume larutan kapur (kalsium oksida) atau 10 menit direbus dalam air beras. Memanggang biskuit daun pepaya carica dalam suhu $60^{\circ} \mathrm{C}$ selama 70 menit dapat mempertahankan kandungan saponin dibandingkan dengan dipanggang pada suhu $130^{\circ} \mathrm{C}$ selama 35 menit. Hasil uji hedonik menunjukkan hal itu ada. Tidak ada perbedaan yang bermakna tingkat akseptabilitas kandungan daun carica papaya antar kelompok. Ratusan gram cookies dengan $40 \%$ daun pepaya carica mengandung $3,67 \mathrm{~g}$ saponin, maka untuk asupan saponin 1,8g / sehari dalam dua kue $25 \mathrm{~g}$ harus dikonsumsi.

Penelitian (Wiyani Ristu, 2019) tentang Bubuk daun pepaya diperoleh bahwa bubuk daun pepaya diasimilasi lebih cepat oleh tubuh dibandingkan dengan daun pepaya yang dimakan langsung, karena siklus retensi dalam tubuh lebih cepat daripada dimakan langsung.
Sebelum diberikan bubuk daun pepaya, umumnya $(75 \%)$ ibu mengalami menyusui tidak lancar, dan hanya $(25 \%)$ mengalami menyusui dengan mudah. Setelah diberikan bubuk daun, disadari bahwa secara praktis seluruh responden (80\%) merasakan ASI lancar dan hanya sebagian kecil (20\%) mengalami ASI tidak lancar. Uji yang digunakan adalah uji opsi Wilcoxon untuk mendapatkan harga $\mathrm{P}$ (Exact.Sig / 2 diikuti) 0,001 ada perbedaan penurunan derajat dispersi ASI saat diberi bubuk daun pepaya. Sejalan dengan itu, H0 ditolak dan H1 diakui, yang berarti ada pengaruh bubuk daun pepaya untuk kesempurnaan menyusui bagi ibu pasca hamil. Hal ini dikarenakan adanya bubuk daun pepaya dan kelenturan yang didapat sang bunda. Bagaimanapun, setelah mereka mendapatkan bubuk pohon pepaya, mereka dapat mengontrol pembentukan ASI.

Penelitian (Mareta et al., 2020) menyebutkan pepaya mengandung karbohidrat, protein, asam amino, glikosida jantung, glikosida saponim, flavonoid, alkaloid, fenolat, dan iridoid. Senyawa fenolik dalam ekstrak pepaya meliputi asam protocatechuic, asam coumaric, asam caffeic;5,7-dimethoxycoumarin, kaempferol, dan quercetin. Pendekatan Insilico menyarankan target baru untuk produksi ASI, 5 senyawa fitokimia hasil seleksi dari 157 molekul galaktagog alami, yaitu Sesamin, Trifoliol, Limonin, Quercetin dan Kaempferol dan terbukti mampu memproduksi lebih banyak produksi ASI dengan mengaktifkan reseptor prolaktin. Hasil penelitian kombinasi galactogogue bubuk instan dari daun pepaya dan jahe merah untuk ibu menyusui menyatakan bahwa daun pepaya mengandung senyawa quercetin yang dapat mengaktifkan reseptor hormon prolaktin, sehingga dapat meningkatkan produksi ASI. Galactogogues adalah makanan, minuman, atau bahan khusus yang dipercaya dapat membantu inisiasi, memelihara, dan meningkatkan ekskresi ASI. Beberapa galaktogog telah mendapatkan reputasi dan pengakuan oleh publik dan profesional sebagai pendekatan alternatif untuk meningkatkan produksi ASI. 
Menurut asumsi peneliti, didapatkan bahwa adanya efektivitas pepaya muda terhadap kelancaran produksi ASI pada ibu menyusui karena kandungan laktogogum memiliki potensi dalam menstimulus hormon oksitosin dan prolaktin seperti alkaloid, polifenol, steroid, flavonoid dalam meningkatkan dan memperlancar pengeluaran ASI. Berdasarkan hasil wawancara yang peneliti lakukan kepada responden bahwa terdapat 2 orang yang tidak mengalami kenaikan berat badan hal ini dikarenakan kurang nya minat ibu dalam mengkonsumsi buah pepaya sesuai takaran yang sudah ditetapkan.

\section{KESIMPULAN}

Hasil penelitian ini diperoleh terdapat keefektifan dari buah pepaya muda terhadap Kelancaran produksi ASI pada ibu menyusui yang ditandai dengan peningkatan berat badan bayi dengan nilai $\mathrm{p}$ value $<\alpha$ yaitu $0,001<$ 0,05 .

\section{DAFTAR PUSTAKA}

[1] (Murtiana. (2011). Faktor Pembelajaran Sosial Dalam Pemberian ASI Eksklusif di Kecamatan Klaten Tengah, Klaten, Jawa Tengah WAHYU RESTIARINI. 1-32.

(Prasetyono.DS. (2009). Pengaruh Pemberian Buah Pepaya ( Carica Papaya L .) terhadap Kelancaran Produksi Air Susu Ibu ( ASI ) pada Ibu Menyusui The Effect of Papaya ( Carica Papaya L .) Towards Breast Milk Production in Breastfeeding Mothers. Medula, 8(April), 39-43.

Aliyanto, W., \& Rosmadewi, R. (2019). Efektifitas Sayur Pepaya Muda dan Sayur Daun Kelor terhadap Produksi ASI pada Ibu Post Partum Primipara. Jurnal Kesehatan, $\quad 10(1), \quad 84$. https://doi.org/10.26630/jk.v10i1.1211

Bahriyah, F., Jaelani, A. K., \& Putri, M. (2017). Hubungan Pekerjaan Ibu Terhadap Pemberian Asi Eksklusif Pada Bayi Di Wilayah Kerja Puskesmas Sipayung. Jurnal Endurance, 2(2), 113. https://doi.org/10.22216/jen.v2i2.1699

$\mathrm{Br}$ Sebayang, W. (2020). PENGARUH KONSUMSI BUAH PEPAYA (Carica Papaya L.) TERHADAP PENINGKATAN PRODUKSI ASI. Jurnal Ilmiah Kebidanan Imelda, 6(1). https://doi.org/10.1533/9780857092618.8 6

Dkk, K. (2011). Pepaya Pada Ibu Postpartum Di BPM Maria Kota Bandar Lampung Tahun 2018. VII(2).

F.B Monika. (2014). Buku Pintar ASI dan Menyusui. Noura Booka.

Ikhlasiah, M. (2020). The effects of papaya leaf juice for breastfeeding and working mothers on increasing prolactin hormone levels and infant's weight in Tangerang. Enfermeria Clinica, 30(5), 202-205.

Istiqomah, Wulandari, A. (2015). J Urnal. Journal Edu Health, 5(2).

Kementerian Kesehatan RI Badan Penelitian dan Pengembangan. (2018). Hasil Utama Riset Kesehatan Dasar. Kementrian Kesehatan Republik Indonesia, 1-100. https://doi.org/1 Desember 2013

Kharisma, Y. (2017). Tinjauan Pemanfaatan Tanaman Pepaya dalam Kesehatan. Laporan Penelitian, 36, 902504.

Mareta, E. W., Suwondo, A., \& Djamaluddin, I. (2020). Comparison Of Effectiveness Benefits Of Providing Young Papaya Fruit Extract And Breast Care For Normal Postpartum Mother's Breast Milk Production: Systematic Review. STRADA Jurnal Ilmiah Kesehatan, 9(2), 11411150.

https://doi.org/10.30994/sjik.v9i2.446

Menti, A. S. (2017). Situasi dan analisis ASI Eksklusif. 6-24.

Muhartono, Graharti, R., \& Gumandang, H. P. (2018). Pengaruh Pemberian Buah Pepaya ( Carica Papaya L .) terhadap Kelancaran Produksi Air Susu Ibu ( ASI ) pada Ibu Menyusui The Effect of Papaya ( Carica Papaya L .) Towards Breast Milk Production in Breastfeeding Mothers. Medula, 8(April), 39-43.

Nataria, D., \& Oktiarini, S. (2018). Peningkatan Produksi ASI dengan Konsumsi Buah Pepaya. Jurnal 
Kesehatan Prima Nusantara Bukittinggi, 9(1), 7-10.

Nugroho, A., Heryani, H., Choi, J. S., \& Park, H. J. (2017). Identification and quantification of flavonoids in Carica papaya leaf and peroxynitrite-scavenging activity. Asian Pacific Journal of Tropical Biomedicine, 7(3), 208-213. https://doi.org/10.1016/j.apjtb.2016.12.00 9

Prasetyaningati, D. (2018). Hubungan Faktor Kesehatan Ibu Postpartum Dengan Penyapihan Dini Di Desa Sidorejo Kecamatan Pare Kabupaten Kediri. JNursing Journal of STIKES Insan Cendekia Medika Jombang, 16(1). http://digilib.stikesicme-

jbg.ac.id/ojs/index.php/jip/article/view/41 9

Riau, D. K. P. (2019). Laporan Kinerja Instansi Pemerintah Tahun 2019. Laporan Kinerja Dinkes.

Wattini, Z. (2010). Konsep penerapan ASI Eklusif. 7-22.

Wijayanti1, K., Subagio2, H. W., Kartasurya3, M. I., \& Sri Achadi Nugraheni3. (2019). ASaponin Maintaining and Dose Determining in Carica Papaya Leaf Cookies as a Breast Milk Booster (galactogogue). Indian Journal of Public Health Research and Development, 10(9), 655-659. https://doi.org/10.5958/09765506.2019.02507.5

Wilda, Ifni, D. (2018). Hubungan Pemberian Asi Eksklusif Dengan Penurunan Berat Badan Ibu Menyusui. Journal Endurance, 3(3), 611-617. https://doi.org/http://doi.org/10.22216/jen .v3i3.2832

Wirdaningsih. (2020). Pengaruh Pemberian Buah Pepaya Terhadap Kelancaran Asi Pada Ibu Menyusui Di Praktek Mandiri Bidan Wilayah Kerja Puskesmas Muara BadaK.

Wiyani Ristu, I. (2019). Pengaruh Pemberian Serbuk Daun Pepaya (Carica Papaya) Terhadap Kelancaran Asi Ibu NifaS. Jurnal Darul Azhar, 7 No 1(1), 45-53.

Yongki. (2012). Asuhan Pertumbuhan Kehamilan Persalinan Neonatus Bayi dan
Balita. Nuha Medika. 